\title{
C 306
}

\section{1 事業所に勤務する女子交代制労働者の睡眠パターン}

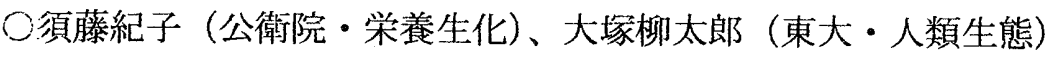

1. 目的 日勤、早番、遅番という三つの異な る勤務時間帯に働く女性の睡眠関連愁訴につい て、月、水、金、日の 4 日間調查し、 3 グルー プ間の違いを明らかにすることを目的とした。

\section{2. 方法}

2-1. 対象 首都圈近県の精密機器工場の女子 従業員 199 名全員を対象に、自記式質問票に よる健康調査を実施した。調査期間は 1998 年 7 月 4 日〜 10 日であった。回収率は 87.4\%(174 名)であった。このうち、睡眠に関するデータ が不完全であった 41 名を除外し、133 名のデ 一夕を本研究の解析に用いた。従業員は日勤者 と交代制勤務者に分かれており、日勤(8:3017:15)は固定しているが、交代制勤務者は 1 週 間毎に早番(6:00-13:45) と遅番(13:40-22:25)を 交代する。調查を実施した週には 46 名が日勤、 42 名が早番、45 名が遅番に従事していた。平 均年齢はそれぞれ $27.3 \pm 4.3$ 歳、26.1 15.8 歳、

$24.9 \pm 4.8$ 歳であった。

2-2. 質問票 前の晚からの睡眠について、就 床・起床時刻、睡眠時間、及び睡眠の質をたず 㸚た。睡眠の質に関しては「日本の産業労働者 のストレスと健康総合調査」（上畑ら、1993） で用いられた「寝つきが悪かった」「あまりに 早く目が覚めた」「夜中に何度も目が覚めた」 「疲れ切ってよく眠れなかった」の 4 項目に ついて、当てはまるものに○をつけてもらい、 その数を Sleep Problem Score とした。月曜日

(Sun-Mon Sleep)、水矅日（Tue-Wed）、金 曜日（Thu-Fri）は始業前に、日睢日 (Sat-Sun) は就床前に記入を求めた。

2-3. 分析 就床時刻、起床時刻、睡眠時間の 3 群間の差の検定には Kruskal Wallis test を
用い、睡眠の質に対する 3 群の勤務時間の影響 は年齢を共変量とした 1 変量分散分析で検定し、 単純対比は日勤を参照水準として行った。

\section{3. 結果}

3-1. 睡眠の長さ 平日の就床及び起床時刻は 早番で最も早く、遅番で最も遅かった $(\mathrm{P}<0.01)$ 。睡眠時間は早番で最も短く、遅番 で最も長かった（P<0.01）。どの群においても、 休日の睡眠時間は平日よりも長かった。

3-2. 睡眠の質 Sun-Mon, Thu-Fri, Sat-Sun の Sleep Problem Score は早番で最も高く、日 勤との単純対比は有意であった。早番内におい ては、Sun-Monのスコア(mean士SE, $1.142 \pm$ 0.116) が 4 日間の中で最も高く、Tue-Wed

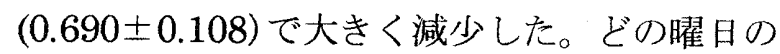
スコアについても、遅番と日勤者の間に有意差 はなかった。

\section{3-3. 睡眠関連愁訴の内容 Sleep Problem} Score の内容には3群間で違いが見られた。早 番の $64.3 \%$ Sun-Mon Sleep において、「葠 つきが悪かった」と訴えていた。

4. 考察 最も高いスコアが Sun-Mon の早番

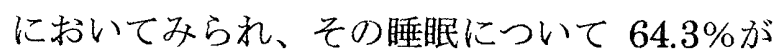

「葠つきが悪かった」と訴えていた。彼女らは 早朝勤務に対して、十分な睡眠時間を確保する ために、早めの就寝に努めており、就床時刻は 最も早かった。しかし、日曜日の夜は睡眠時間 の長い休日明けのため、入眠が困難となり、寝 つきの亜さを訴えるものが多くなったと考えら れた。また、遅番から早番へのシフトは適応が 困難であるとされる Backward Rotation であ るため、新しいシフトの始まりである Sun-Mon のスコアが最も高かったと考えられた。 